110 Nordic Council of Ministers

\title{
EXCERPTS FROM THE FREEDOM OF MOVEMENT COUNCIL ANNUAL REPORT 2017
} WITH COMMENTS FROM THE NORDIC GOVERNMENTS

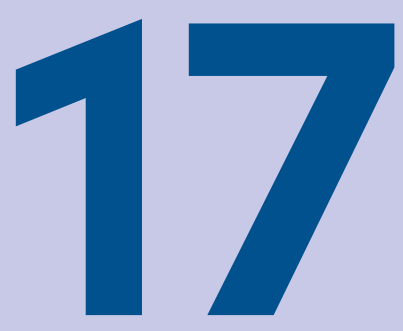


Excerpts from the Freedom of Movement Council annual report 2017

With comments from the Nordic governments

\section{ANP 2018:833}

ISBN 978-92-893-5889-7 (PRINT)

ISBN 978-92-893-5890-3 (PDF)

ISBN 978-92-893-5891-O (EPUB)

http://dx.doi.org/10.6027/ANP2018-833

(c) Nordic Council of Ministers 2018

Layout: Peter Daniel Olsen/Resonans Kommunikation

Print: Hillerød Grafisk

Printed in Denmark

\section{Nordic co-operation}

Nordic co-operation is one of the world's most extensive forms of regional collaboration, involving Denmark, Finland, Iceland, Norway, Sweden, the Faroe Islands, Greenland, and Åland.

Nordic co-operation has firm traditions in politics, the economy, and culture. It plays an important role in European and international collaboration, and aims at creating a strong Nordic community in a strong Europe.

Nordic co-operation seeks to safeguard Nordic and regional interests and principles in the global community. Shared Nordic values help the region solidify its position as one of the world's most innovative and competitive.

\section{Nordic Council of Ministers \\ Nordens Hus \\ Ved Stranden 18 \\ DK-1061 Copenhagen \\ www.norden.org}

Download and order Nordic publications from www.norden.org/nordpub 
(1) Nordic Council of Ministers

\section{EXCERPTS FROM THE FREEDOM OF MOVEMENT COUNCIL ANNUAL REPORT 2017}

WITH COMMENTS FROM THE NORDIC GOVERNMENTS

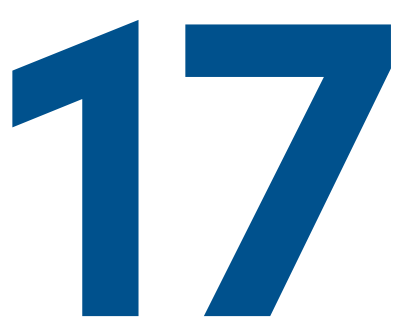




\section{Contents}

7 Prime Ministers' Declaration

8 Organisation of the work of the Freedom of Movement Council

12 Status of the prioritised cross-border obstacles in 2017

15 Obstacles relating to the labour market

19 Obstacles relating to business

23 Other obstacles

26 Cross-border obstacles concluded 2014-2017

30 Information work

33 Mandate of the Freedom of Movement Council, 2018-2021

Please note that this document is not a complete version of the Freedom of Movement Council's annual report. The report is available in the Scandinavian languages at norden.org. 



\title{
Background to the work of the Freedom of Movement Council in 2018
}

\author{
The Nordic Prime Ministers' Declaration in response to the new strategy and \\ action plan for removal of cross-border obstacles in the Nordic region. The \\ new strategy and action plan was discussed at the 65th Session of the \\ Nordic Council in October 2013.
}

\author{
The Nordic region as a forerunner for co-operation on freedom of movement, \\ to create jobs and growth.
}

\begin{abstract}
We, the prime ministers of Denmark, Finland, Iceland, Norway and Sweden, the premier of the Faroe Islands, the prime minister of Greenland and the premier of Åland agree that the removal of obstacles to freedom of movement, to create jobs and growth in the Nordic region, is one of the key challenges facing Nordic co-operation. This applies not least in our common need to help young people into the labour market.
\end{abstract}

By creating optimal conditions for individuals and businesses to operate across borders in the Nordic region, we are strengthening the global competitiveness of the region.

\begin{abstract}
A strongly prioritised initiative is therefore the work to actively remove cross-border obstacles. These obstacles are costly, restrict development and growth, and reduce options for the individual.
\end{abstract}

The work of the Freedom of Movement Forum, set up by the Nordic Prime Ministers in 2007, has been valuable in removing obstacles to freedom of movement in the Nordic region. To strengthen and streamline this work, we are now developing the organisation for a Freedom of Movement Council, with a new strategy and action plan that will come into force on 1 January 2014.

This means that:

- The work will be more closely linked to the political leadership in the Nordic Council of Ministers. The country holding the presidency in the Nordic Council of Ministers will also be the president of the Freedom of Movement Council.
- The Secretary General of the Nordic Council of Ministers will have a stronger role in the work on freedom of movement on behalf of the Council of Ministers.

- The national representatives on the Freedom of Movement Council will have a clear remit to collaborate with the parties that can help remove obstacles for individuals and businesses in the Nordic region. This collaboration will include the ministries and public agencies in the countries, parliamentarians, and the regional information services in the border areas.

The new form of the work on freedom of movement in the Nordic region will improve the efficiency of the work on removing obstacles, and increase crossborder movement in the Nordic region.

In order to attain this, our goals should be:

- to work for an open and properly functioning common labour market.

- to create the best possible conditions for Nordic businesses to operate across borders in the Nordic region.

- to ensure, as far as possible, similar implementation of EU legislation in the Nordic region through continual dialogue between the Nordic countries.

- to ensure that the countries consult with each other, when necessary, when new or revised laws and regulations are introduced, to prevent the formation of new cross-border obstacles. 


\section{Organisation of the work of the Freedom of Movement Council}

The Freedom of Movement Council consists of ten members.

Eight appointed by the ministers for co-operation of, respectively, Denmark, Finland, the Faroese Islands, Norway, Iceland, Greenland, Sweden and Åland, plus a representative of the Nordic Council and the Secretary General of the Nordic Council of Ministers.

It is very important that the work of the Freedom of Movement Council, both regionally and nationally, is linked to the relevant Nordic Council of Ministers and to the relevant national ministries and parliaments. This is to create transparency and participation in the Nordic work to remove the cross-border obstacles identified by individuals and businesses throughout the Nordic region.

The illustration shows how the work of the Freedom of Movement Council is organised.

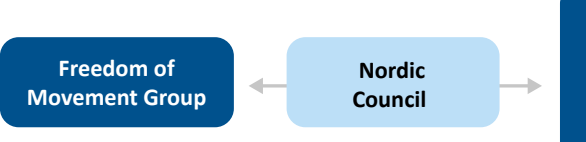

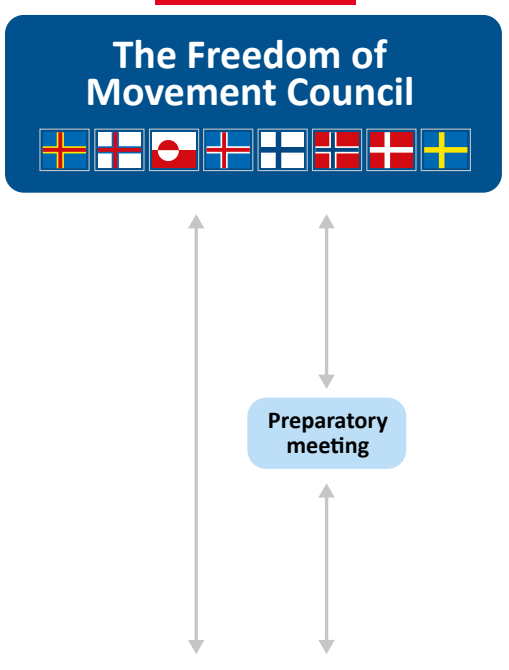

Nordic Council of
Ministers Secretariat

Coordination
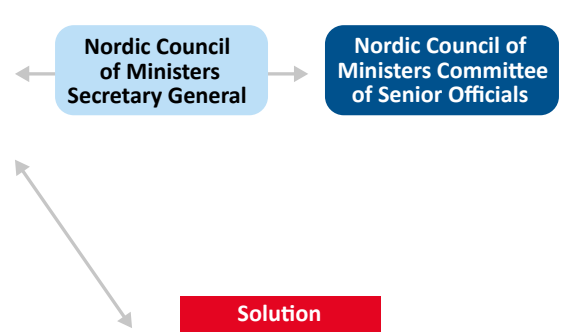

Solution
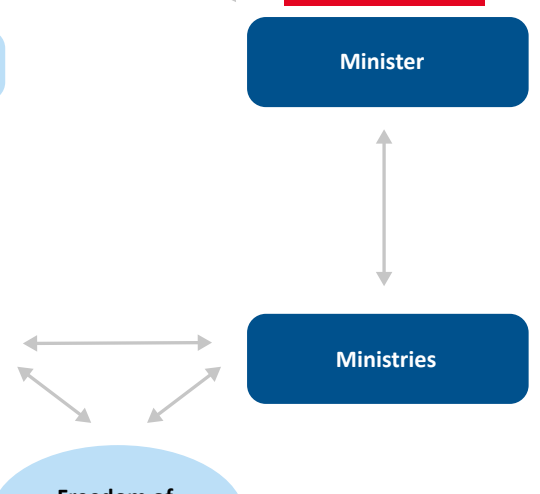

Freedom of Movement Database

Documentation 


\section{Identification}

Cross-border obstacles are identified in situations where citizens and businesses seek information on moving across the Nordic borders. To meet the information needs of citizens, regional information services have been set up in the Nordic region - Øresunddirekt between Denmark and Sweden, Grensetjänsten Sverige/Norge between Sweden and Norway, and Nordkalottens Gränstjänst between Finland, Norway and Sweden. There is also the Nordic information service, Hello Norden, which is located in the Nordic capitals. The information services identify cross-border obstacles, and report them to the Secretariat of the Nordic Council of Ministers, and convey information via the web, email, telephone, and personal service, and in information meetings for private individuals and businesses.

\section{Coordination}

The Secretariat is responsible for coordinating the work of the Freedom of Movement Council. The Secretariat also coordinates the work of the Council with the similar work being carried out in the Secretariat of the Nordic Council of Ministers under each Council of Ministers. The Secretariat also coordinates the work of the information services in relation to a joint action plan that will increase collaboration and rationalise the work on freedom of movement and information.

\section{Documentation}

All identified cross-border obstacles are documented in the Freedom of Movement Database. The ministries concerned check the quality of the content in the database.

\section{Prioritisation of obstacles}

To create a long-term approach and structure in the work to remove cross-border obstacles, each member of the Freedom of Movement Council selects 3-5 obstacles that are to be prioritised. These are selected from the obstacles registered in the Freedom of Movement Database. The members of the council may choose to prioritise certain obstacles jointly. The members may also focus on obstacles identified as being acute, and that are particularly important to resolve during the year.
The national members court the ministry and ministries concerned, until a decision is made on whether the obstacle can be removed or whether the ministry has decided not to proceed with work to remove the obstacle. If an obstacle is discontinued in this way, the Freedom of Movement Council members prioritise a new obstacle to work with. The Annual Report of the Freedom of Movement Council contains a status update from the Council's members and the ministries concerned, enabling monitoring of the process regarding the prioritised obstacles.

The Nordic Council of Ministers' representative on the Freedom of Movement Council coordinates the work of the Council with the work carried out in the relevant Council of Ministers to remove obstacles. The Nordic Council's representative on the Freedom of Movement Council coordinates the work of the Council with the work carried out in the Nordic Council, whose members can raise the issue of the prioritised obstacles in their national parliaments.

\section{Solution}

Only decision-makers in the Nordic countries, the Faroe Islands, Greenland and Åland can find solutions to the identified obstacles. However, the Freedom of Movement Council can work to remove obstacles that hinder mobility and growth for citizens and businesses in the Nordic region. The Council does this by describing the problem in detail, proposing solutions and, where possible, preparing cost analyses. The Freedom of Movement Council works according to its remit from the Nordic Prime Ministers, and therefore emphasises collaboration and open dialogue with the ministries and public agencies affected by the obstacles to free movement. 


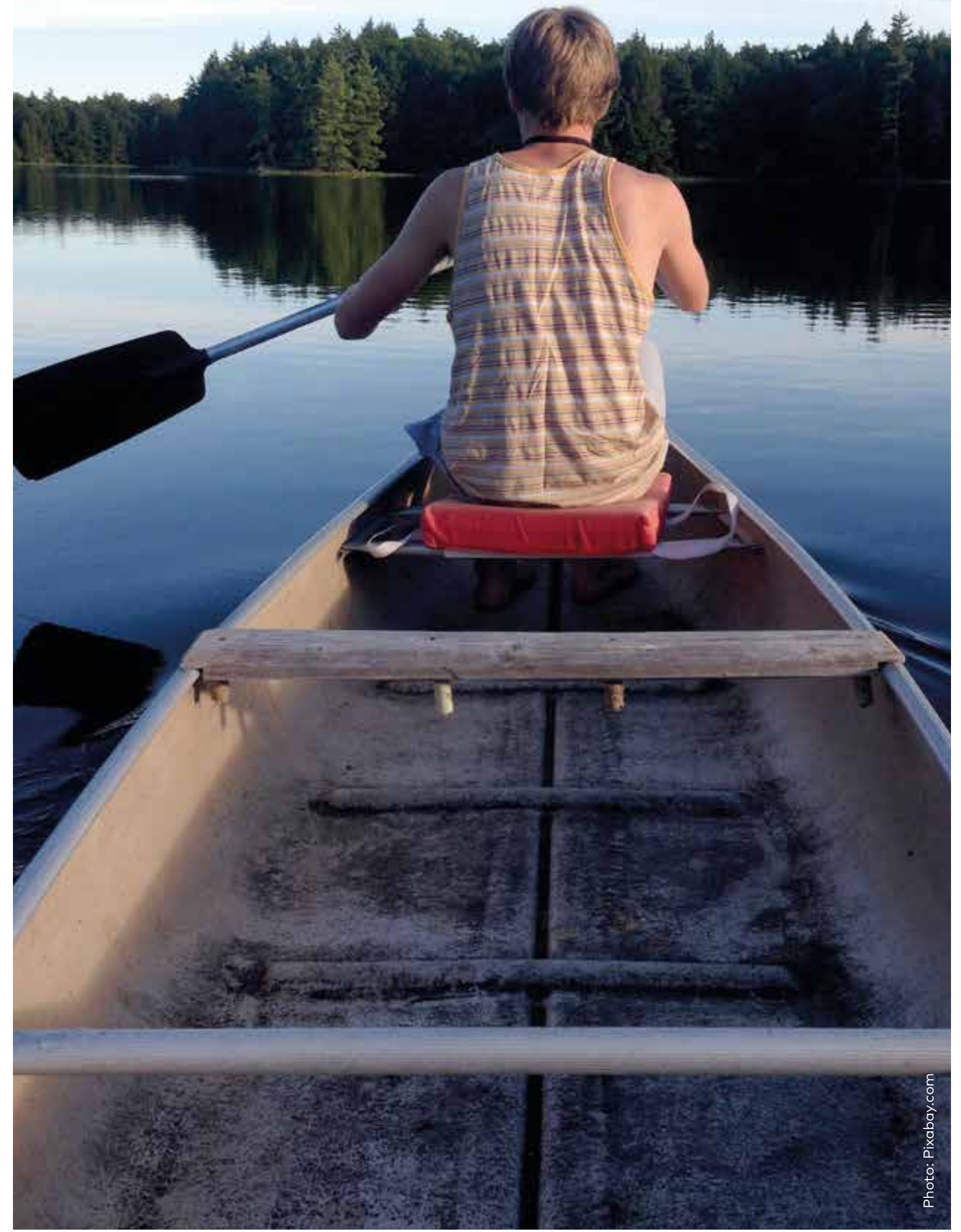




\section{Goals of the Freedom of Movement Council}

The Freedom of Movement Council prioritises obstacles that arise in the labour market, social and education areas, comprising laws, statutory regulations or practices that hinder the mobility of the individual or the ability of businesses to operate across Nordic borders.

The Freedom of Movement Council works with the obstacles identified at grassroots level, i.e. obstacles identified by Hello Norden, Grensetjänsten SverigeNorge, Øresunddirekt and Nordkalottens Gränstjänst.

The goal is that 8-12 obstacles will be removed each year as a result of the work of the Freedom of Movement Council.

\section{Prioritised cross-border obstacles}

The members of the Freedom of Movement Council grade the work with their prioritised obstacles according to a four-level colour scale.

Blue means that a final decision has been received from the ministry concerned. The heading shows whether the obstacle has actually been resolved or whether the countries have decided not to resolve the obstacle and discontinue the work to find a solution.

Green means that the work is following the process that each member has set up to obtain a final decision on whether the obstacle will be resolved or not.

Yellow means that some sort of work is going on with the obstacle at the ministry concerned.

Red means that the obstacle is not currently a priority for the ministry or agencies concerned.

The 2017 Annual Report contains an update on the status regarding the obstacles prioritised by the members of the Freedom of Movement Council.

It is important to note that the status given for obstacles that are not resolved or discontinued may have changed since the report was printed. It should also be noted that the governments of the Nordic countries may assess the obstacles differently from the members of the Freedom of Movement Council.

\section{Definition of cross-border obstacles}

In the Nordic co-operation regarding freedom of movement, obstacles are "laws, statutory regulations or practices that restrict the mobility of the individual or the ability of businesses to operate across Nordic borders." The different levels of wages and taxes in the Nordic countries are not cross-border obstacles. However, it is regarded as an obstacle if a person, on account of their mobility, is treated differently to other people in a comparable situation, both in the country of residence and the country of work.

To facilitate identification, reporting and quality assurance of obstacles, in 2017 the Secretariat of the Freedom of Movement Council prepared a checklist based on the definition of an obstacle in the mandate of the Freedom of Movement Council. The checklist includes a number of criteria that a tangible issue must satisfy in order to qualify as an obstacle.

\section{Calculations}

When we calculated the costs involved in specific cross-border obstacles, we used existing statistics as far as possible. Where no current statistics were available, we used estimates based on older statistical information. In individual cases, we were forced to make assumptions to illustrate the costs; in such cases, this is pointed out in connection with the calculations. 


\section{Status of the prioritised cross-border obstacles in 2017}

A person applying to an incorrect unemployment insurance fund (A-kassa) may lose their right to unemployment benefit

Right to leave of absence for political activities when working in another Nordic country

Requirement to be covered by different countries' unemployment insurance without a break to avoid risk of lower unemployment benefit

Age limit for joining a Swedish unemployment insurance fund

Right to income-related unemployment benefit in Sweden after receiving work assessment benefit from Norway

Obstacles relating to education

The EU mobility programme, Sweden

Recognition of professional qualifications

Limited opportunity for Swedish doctors to carry out their internship in Åland

Application to upper secondary education in Norway

Obstacles relating to social services and health

Compensation for travel costs for patients between Norway and Finland/Sweden

Finnish four-month rule

Movement for institutionalised people

Different requirements for labelling of medicines and language on patient information leaflet

No benefits for care of closely related persons unless both care-provider and the patient are insured in Sweden

Mobility service for disabled people

Guide dog when travelling

Personal assistant when moving

Movement with disability vehicle

Right to unemployment benefit after being laid off and being given notice after work in Norway 
Temporary import of horses between Norway and Sweden

Norwegian internal tax practices make it difficult to execute assignments in the construction sector

Transportation of valuables across borders

Customs and deposits in connection with import of goods

Mobile food premises as first place of entry in Finland

Import of Norwegian salmon fry to Sweden

Faroese tachograph

Different building provisions

Lack of information for small and medium-sized companies when operating in other Nordic countries

Other obstacles

Co-ordination number for foreign owners of holiday homes in Sweden

Recognition of Faroese driving licence

Recognition of Greenlandic driving licence

Digital tools for communicating with public authorities do not work across Nordic borders

Recognition of parenthood for families where the parents are of the same gender Norwegian regulations for helicopter traffic make it difficult to maintain reindeer fences in Norway

Norwegian customs regulations make it difficult to maintain reindeer fences in Norway

Documentation requirements for registration in the National Registry in Norway

Requirement to exchange foreign driving licences in Denmark 
gese

26

4

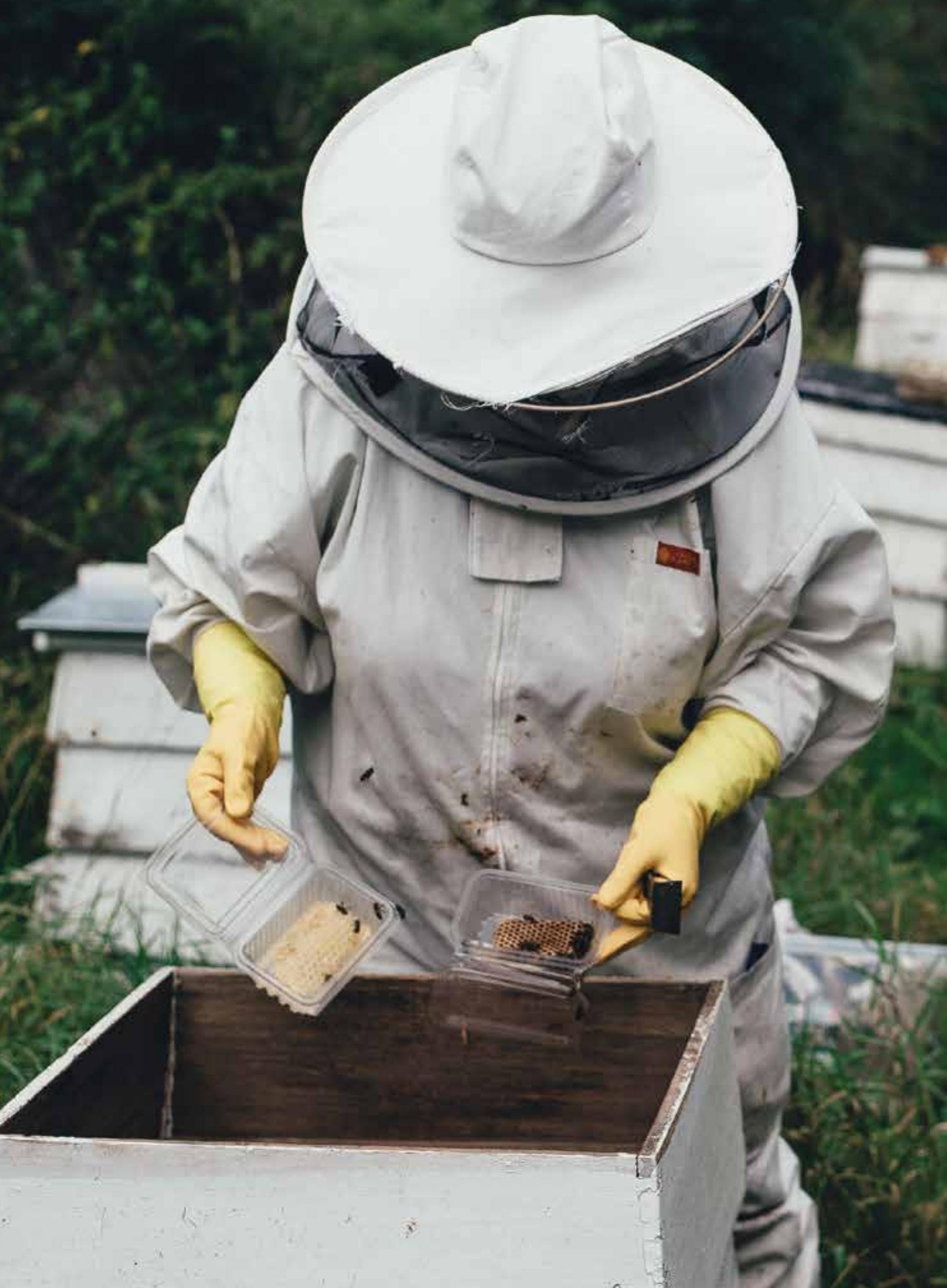




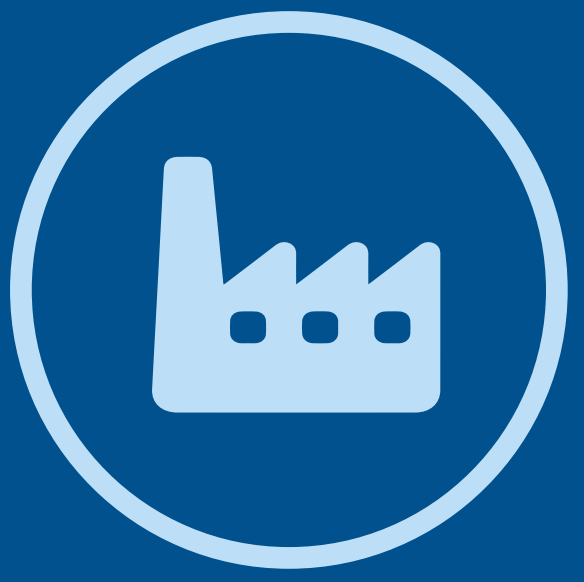

Obstacles relating to the labour market 


\title{
Requirement to be covered by different countries' unemployment insurance without a break to avoid risk of lower unemployment benefit
}

\author{
An employee whose membership of a Swedish unemployment insurance \\ fund is not continuous risks losing the right to income-related insurance \\ benefit, and only receiving the lower basic amount. A break can occur, for \\ example, if an employee starts working in a country other than Sweden, or \\ when a cross-border worker returns to Sweden and applies for unemployment \\ benefit. A break can also occur for people who only live and work in Sweden.
}

\begin{abstract}
Obstacle prioritised by Eva Tarselius Hallgren, Sweden. Also prioritised by the Nordic Council of Ministers for Labour (MR-A).
\end{abstract}

The obstacle can be resolved by the Ministry of Employment in Sweden.

Prioritised by the Freedom of Movement Council since 2015.

\section{Background}

Sweden has a two-part unemployment insurance system. The general element, basic insurance, covers employees and the self-employed. The voluntary element, loss-of-income insurance, covers people who have been members of an unemployment insurance fund for at least 12 months. According to Swedish practice, entitlement to this income-related unemployment benefit requires 12 months' continuous membership of a Swedish unemployment insurance fund or an equivalent period of insurance from work in another Nordic country. Employees who have a break in the membership period in a Swedish unemployment insurance fund risk losing the right to income-related unemployment benefit, and only receiving the lower basic amount.

From the Swedish viewpoint, this cross-border obstacle impacts people covered by loss-of-income insurance who start working in another country without taking out unemployment insurance there. This can occur, for example, in Denmark, where unemployment insurance is voluntary. If the person does not immediately become a member of an unemployment insur- ance fund in Denmark, he or she is at risk of a break in insurance cover. This can mean that the person in question, in a subsequent assessment in Sweden, may only be granted benefit from the Swedish basic insurance.

A break in the insurance period may also occur if a person has been working in another country and, on return, does not immediately join a Swedish unemployment insurance fund, or applies for membership of the wrong unemployment fund (see the obstacle 'A person applying to an incorrect unemployment insurance fund (A-kassa) may lose their right to unemployment benefit').

In cases where the 'five-year rule' in the Nordic Convention on Social Security applies, a person may be readmitted to a Nordic country's unemployment insurance system provided they apply within eight weeks of leaving another Nordic country's system. Consequently, there is less risk of a break in insurance cover on re-entering the Swedish unemployment insurance system in cases where the Nordic Convention applies. 
The obstacle corresponds to obstacle B12 in the report Freedom of Movement within the Social and Labour-market Area in the Nordic Countries (Nord 2012:002).

\section{Who is affected?}

People who do not maintain a continuous period of insurance (membership period) when they start to work in another country or return to Sweden.

\section{Legal background}

According to Swedish practice, there is a requirement for 12 months' continuous membership of a Swedish unemployment insurance fund or an equivalent period of insurance from work in another Nordic country.

\section{Proposed solution}

In the report Nord 2012:002, a Nordic expert group identified a need for clarification of the legislation regarding the requirement to have 12 months' continuous membership of an unemployment insurance fund in order to be entitled to benefit from loss-of-income insurance in Sweden. Such a clarification could mean that a period would be regarded as unbroken even if a certain proportion of it was de facto uninsured. The 'eight-week rule' operated by Danish unemployment insurance might provide guidance here.

\section{Freedom of Movement Council work on the issue/Comments from the governments concerned}

Ministry of Employment, Sweden:

The Swedish Ministry of Employment is currently undertaking an internal review of unemployment insurance. The review concerns, for example, issues of breaks in membership and certain other issues that were previously investigated by the Parliamentary Social Insurance Committee. A ministerial report was referred in December 2016, and the Swedish Government submitted a bill to the Swedish Parliament in November 2017.

The Bill includes a proposal that the law should clearly show that the right to income-related unemployment benefit requires continuous membership for at least twelve months. Furthermore, the Government, or a public agency determined by the Government, should be able to notify regulations about certain breaks in membership that the unemployment fund should disregard when assessing the terms of membership. The proposal is that the new regulations should come into force in 2018.

Read more in the Freedom of Movement Database, www.norden.org/da/graensehindringer, Border Obstacle no. 14-004. 


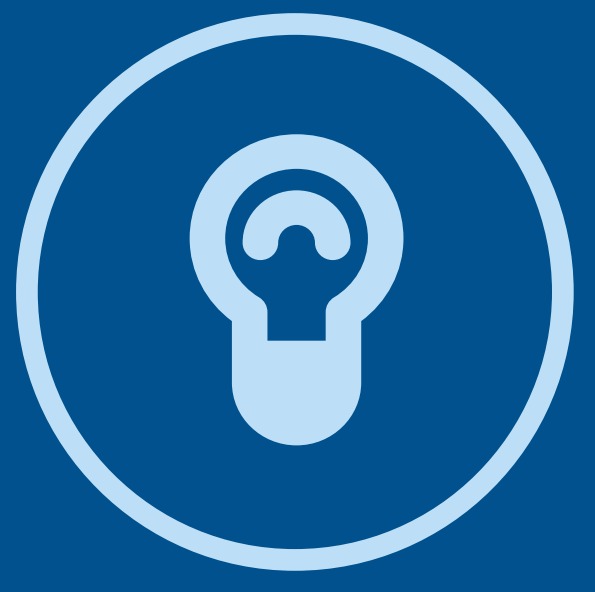

Obstacles relating to business 


\section{Mobile food premises as place of first arrival in Finland}

Obstacle prioritised by Risto E.J. Penttilä, Finland, since 2017.

Prioritised by the Freedom of Movement Council since 2017.

\section{Background}

According to a decision of the Finnish Food Safety Authority, Evira, mobile food premises may not serve as the place of first arrival for foodstuffs of animal origin that are imported to Finland. This restricts Swedish companies who wish to sell fresh animal-based products from Sweden in Finland using, for example, a refrigerated vehicle. When a foodstuff of animal origin arrives in Finland from another EU country, it must first be taken to a place of first arrival for inspection. Approved establishments include slaughterhouses, butcheries or storage facilities. Places of first arrival may also be food shops, restaurants or large-scale kitchens.

According to the Finnish Food Law, mobile food premises are any mobile or temporary place or equipment where foodstuffs are sold or handled. Examples are a mobile stand, a sales van, or tent (Food Law 23/2006, 1137/2008, Section 6, point 18 a). The regulations on food safety are largely based on EU regulation 852/2004, but similar requirements regarding places of first arrival are not stipulated in the regulation. Denmark and Sweden do not place such requirements on specific places of first arrival for foodstuffs of animal origin imported from other EU countries, and in legislation refer instead to the EU regulations in the area.

\section{Practical example}

The small company, FISK Ab, based in Pajala, sells fresh fish from a refrigerated vehicle in towns and villages on the Swedish side of the Tornedalen valley. The company wants to expand its customer base, and wishes to be able to drive around and sell fish on both sides of the border. However, the Swedish company's plans are made impossible because, on the Finnish side of the border, mobile food premises, in this case a refrigerated vehicle, are not approved as the place of first arrival. The company lacks the capacity to use, for example, a slaughterhouse as the place of first arrival in Finland.

\section{Proposed solution}

The Finnish Food Safety Authority should change its practices so that mobile premises can be approved if they are already registered and approved in other EU countries. For example, the following is taken from the Swedish National Food Agency's guidelines on approval of food premises from 2009, point 9.4.1: "If a mobile facility is approved by or registered in a supervisory authority in another country in the EU, this corresponds to a Swedish registration or a Swedish approval. This should also apply to countries within the EEA, such as Norway." Furthermore, a mobile food facility approved in another country should be usable as a place of first arrival for foods of animal origin in Finland.

\section{Freedom of Movement Council work on the issue/Comments from the governments concerned}

\section{Risto E.J. Penttilä, Finland:}

The issue is expected to be resolved in conjunction with a major revision of food legislation.

Read more in the Freedom of Movement Database, www.norden.org/da/graensehindringer, Border Obstacle no. 17-008. 


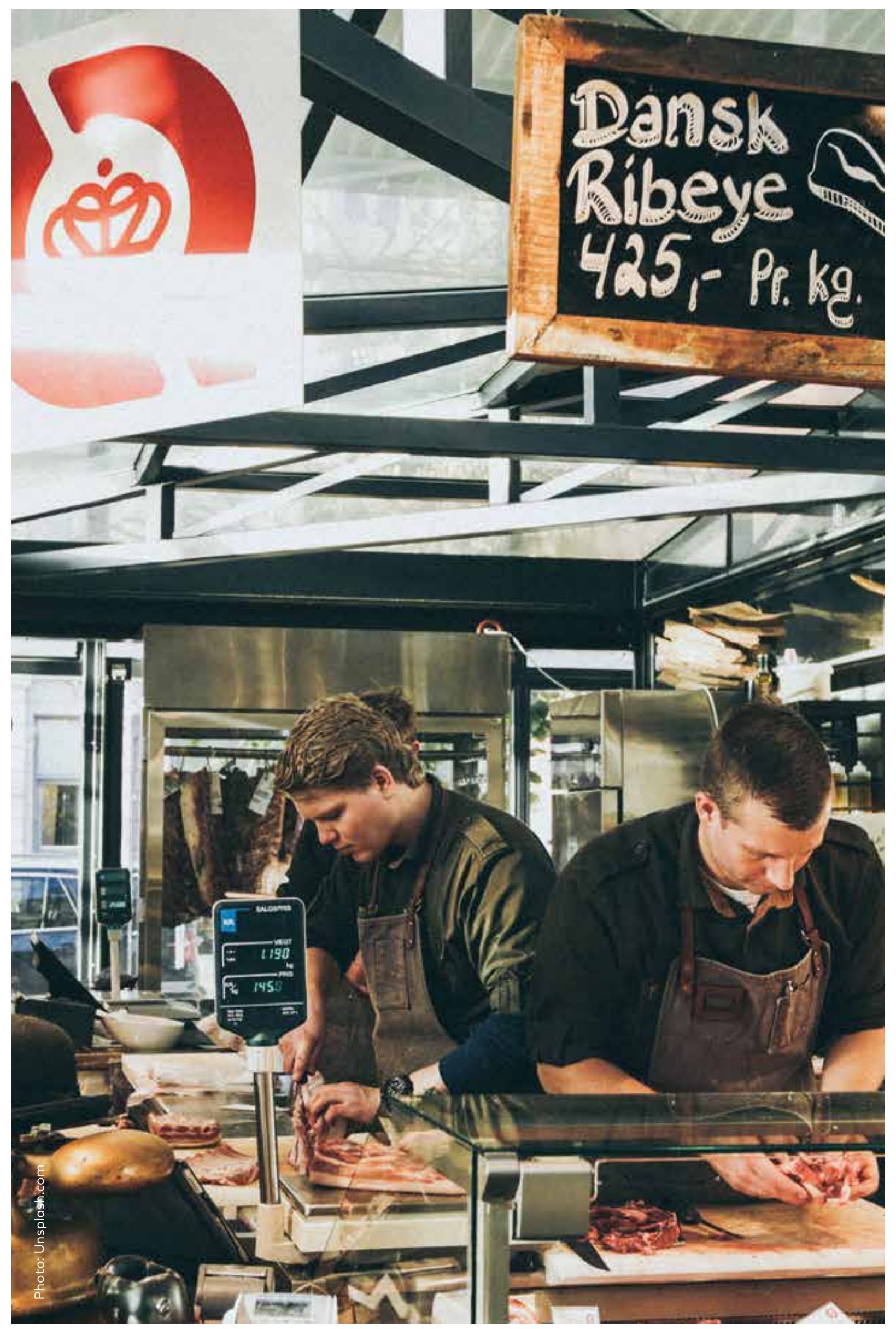


$\rightarrow 2 y+2=$

wothens?

$320^{6}-5056=0$

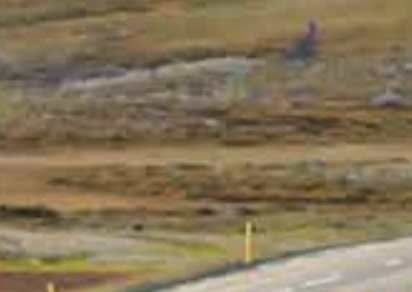

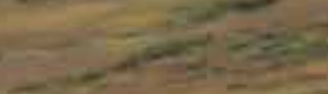

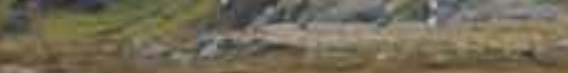

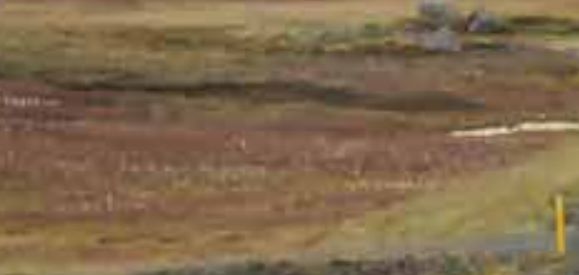

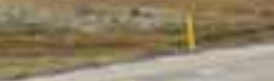

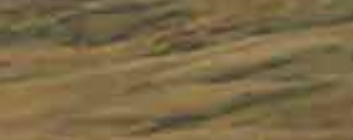

$-x^{2}-1=$

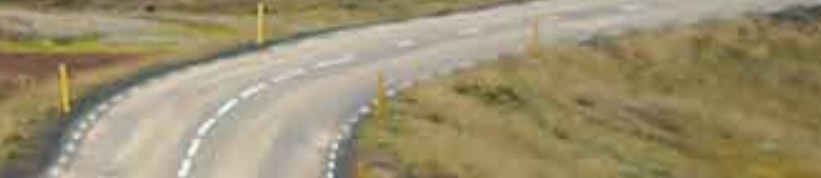

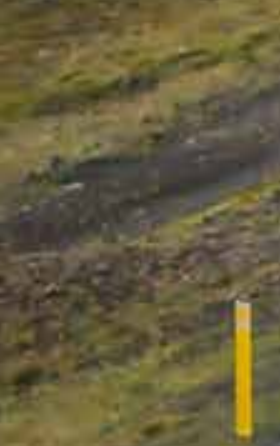

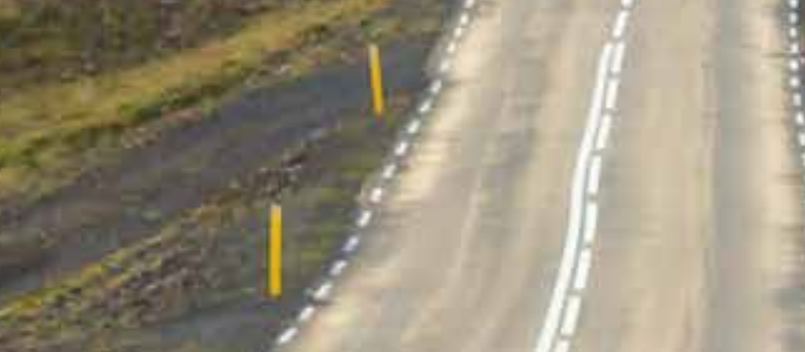

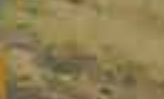
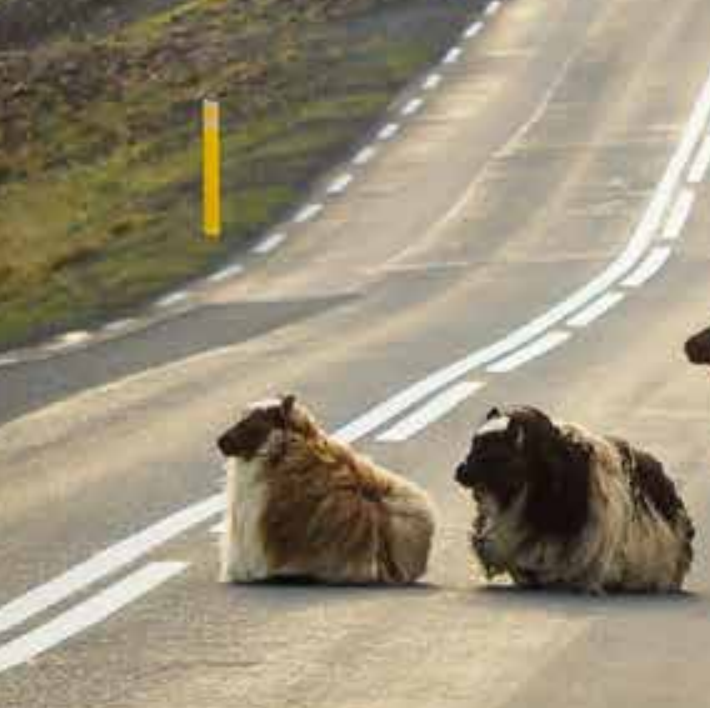

seci

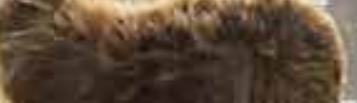

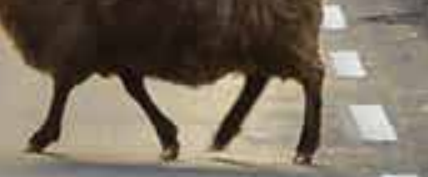

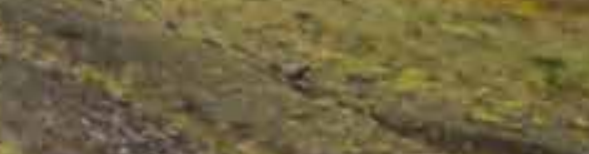

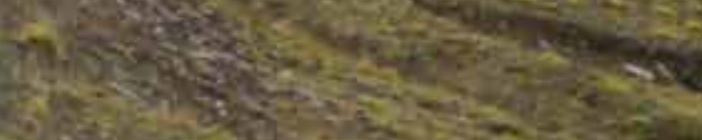
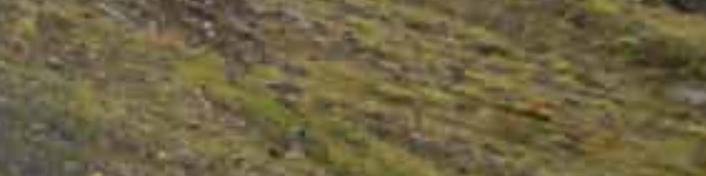

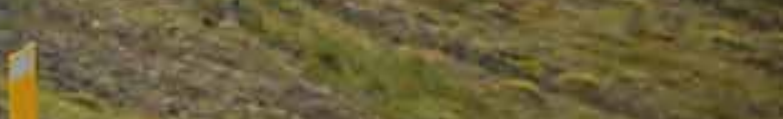

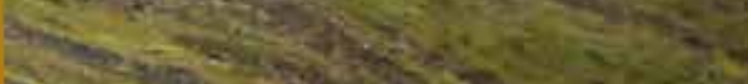

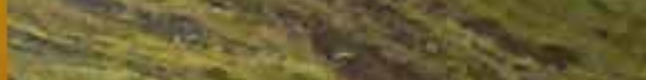

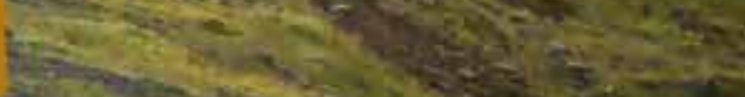

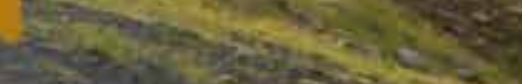
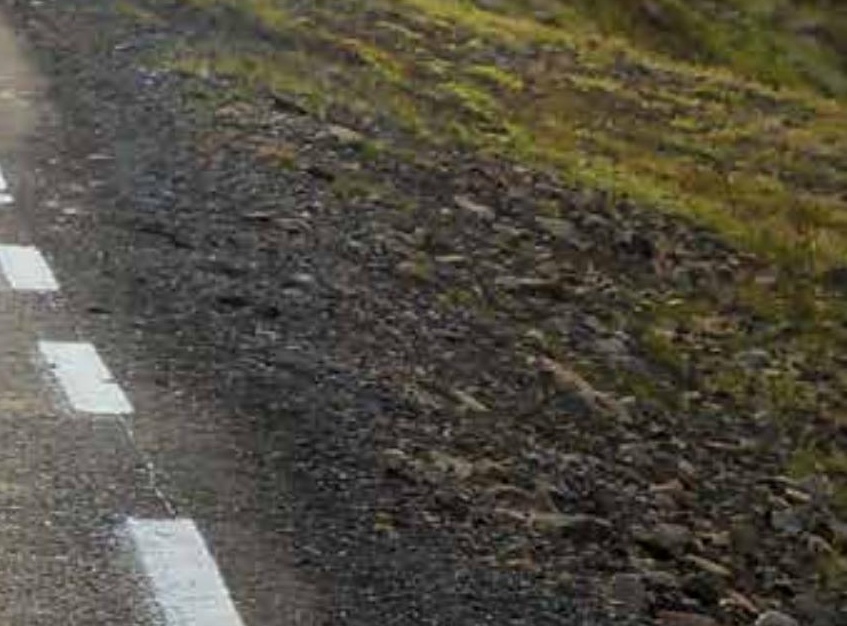
Other obstacles 


\section{Co-ordination number for foreign owners of holiday homes in Sweden}

\section{Foreign owners of holiday homes in Sweden experience problems obtaining electricity, telephone and Internet agreements because they have neither a personal ID number nor a co-ordination number.}

Obstacle prioritised by Eva Tarselius Hallgren, Sweden.

The obstacle can be resolved by the Swedish Ministry of Finance (but not completely, as a co-ordination number cannot replace a personal ID number in all respects).

Prioritised by the Freedom of Movement Council since 2014.

\section{Background \\ Even if the issue concerns a small group of people, it nevertheless shows clearly the consequences when a person lacks a personal ID number. This applies particularly in Sweden, where systems for utilities, services and trade are based on personal ID numbers. When paying property fees, etc., foreign owners of holiday homes must use a 'GD number', which they use in contact with the Swedish Tax Agency. This number is not widely used in society.}

The number has virtually no function in contact with private actors, which leads to problems when trying to obtain, for example, electricity, telephone and Internet agreements. Foreign owners of holiday homes therefore need to get a 'co-ordination number', used in society through SPAR, the personal address registry.

\section{Who is affected?}

Foreign owners of holiday homes in Sweden, totalling approximately 36,500 people, of which approximately 22,500 come from Denmark, Norway or Finland, are affected. Of these, $78 \%$, approximately 28,700 people, have stated that they need a co-ordination number, according to calculations by $\varnothing$ resundsinstituttet.

\section{Financial consequences}

According to a study carried out by the Swedish Tax Agency in 2014, it would cost approximately SEK 19 million, a one-off investment, to replace the existing GD number, which is registered for foreign property owners, with a co-ordination number. In addition, there would be development costs. In the same study by the Swedish Tax Agency, annual savings derived from replacing a GD number used for foreign owners of holiday homes were estimated at SEK 270,000 SEK.

If half of the foreign owners of holiday homes reporting that they need a co-ordination number were then to take out a TV contract for SEK 269/month, this would help to increase sales of TV agreements by approximately SEK 46 million. More detailed calculations are shown below.

\section{Proposed solution}

Co-ordination numbers should also be assigned to foreign owners of holiday homes.

\section{Freedom of Movement Council work on the issue/Comments from the governments concerned}

Ministry of Finance, Sweden:

The Ministry of Finance's work with the issue of coordination numbers for foreign owners of holiday homes requires continued dialogue with the Swedish Tax Agency and Lantmäteriet. The Ministry of Finance is also working with necessary statutory changes and with the issue of how to solve the funding issue.

Read more in the Freedom of Movement Database, www.norden.org/da/graensehindringer, Border Obstacle no. 14-160. 


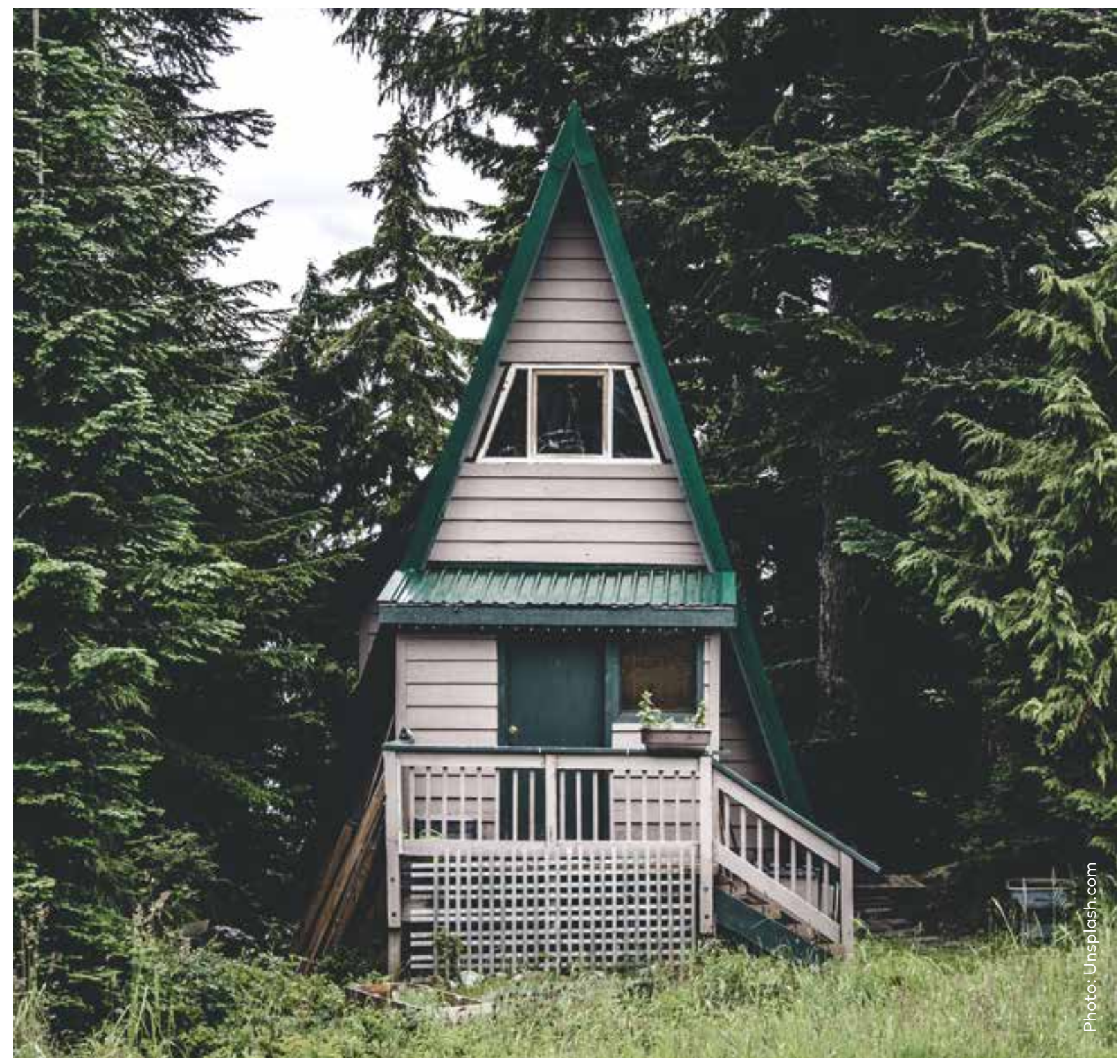

\section{Calculations by Øresundsinstittutet}

\begin{tabular}{|c|c|c|}
\hline Number of foreign owners of holiday homes in Sweden & 36,761 & people \\
\hline Norwegians & 11,605 & people \\
\hline Finns & 235 & people \\
\hline Danes & 11,605 & people \\
\hline Others & 13,316 & people \\
\hline Proportion in need of a co-ordination number $=78 \%$ & 28,674 & people \\
\hline If half of these enter into a TV agreement (calculated for the Boxer Mix package) & 14,337 & people \\
\hline Cost of TV agreement/month & 269 & SEK \\
\hline Total annual expense for foreign owners of holiday homes, for TV agreements alone & $46,279,158$ & SEK \\
\hline Cost of introducing co-ordination numbers & $19,000,000$ & SEK \\
\hline
\end{tabular}




\section{Cross-border obstacles concluded 2014-2017 Concluded: resolved.}

\section{7}

EU mobility programme, Sweden

Limited opportunity for Swedish doctors to carry out their internship on Åland

Lack of information for small and medium-sized companies when operating in other Nordic countries

Norwegian regulations for helicopter traffic make it difficult to maintain reindeer fences in Norway

Norwegian customs regulations make it difficult to maintain reindeer fences in Norway

Guide dog when travelling, resolved in Norway

\section{6}

Right to unemployment benefit after work assessment allowance from Norway

EU mobility programme, Iceland

State educational support for employees on study leave

Recognition of Greenlandic educational qualifications

Norwegian customs and VAT regulations for Nordic companies

Commercial passenger vessel traffic across the border between Sweden and Norway

Regional statistics

Authorisation for Swedish drivers of snowmobiles to drive in Norway 


\section{5}

Work rehabilitation in the country of residence

Processing time regarding social insurance in Norway

No right to educational support after work abroad

Students' social insurance in another Nordic country

Dual taxation Greenland and Sweden/Finland

Taxation of Danish capital pension

Procedures regarding tax affairs for genuine cross-border commuters (Norway)

Taxation of foreign pensioners in the country of residence

Payment of value-added tax when importing a work machine from Norway to Sweden

Finnish safety requirements regarding temporary import of caravans, snowmobiles, etc.

Arjeplog Agreement BLUE

\section{4}

Language requirements for Danish occupational qualifications

Problems when moving to Iceland with the qualification period of 6 months when the E-104 form is lacking 


\section{Concluded: not resolved. Discontinued by the ministry concerned.}

\section{7}

Right to income-related unemployment benefit in Sweden after work assessment benefit from Norway

Movement with disability vehicle

\section{6}

Limited possibilities for cross-border workers to commute to Norway

Problems relating to permanently employed cultural workers in Sweden

Procedures for tax payments relating to genuine cross-border commuters

Electricity tariffs for Åland

Obstacles deriving from the Nordic tax agreement

- Problems relating to permanently employed cultural workers in Sweden

- Procedures for tax payments relating to genuine cross-border commuters

- Taxation of payments from foreign pensioners in the country of residence and payments according to a country's social legislation

- Taxation of student grants

\section{5}

The paternal quota in Norway

\section{4}

Work placement in another Nordic country 


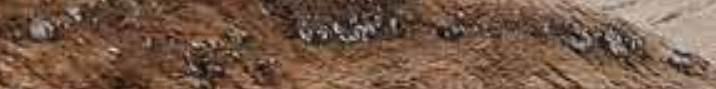

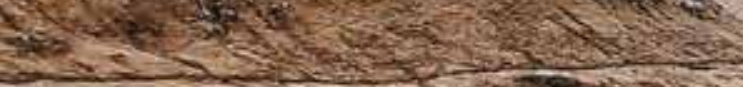

(1)

pand $7=7$

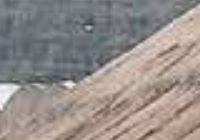

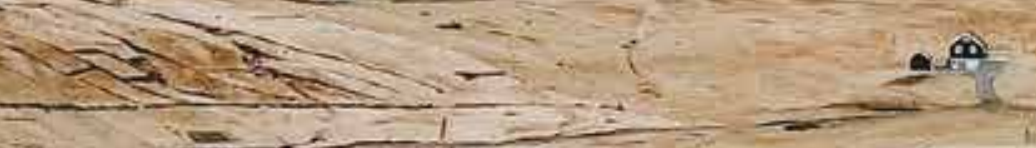

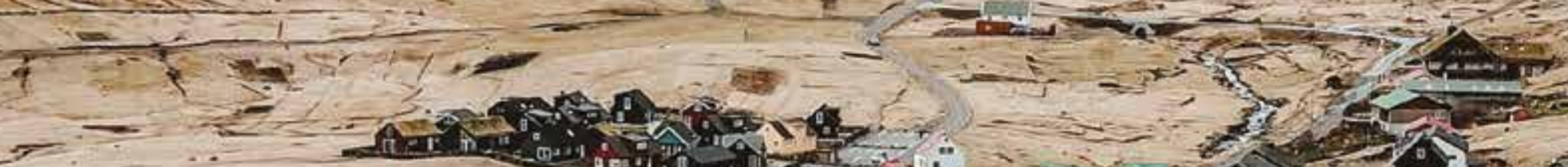
now

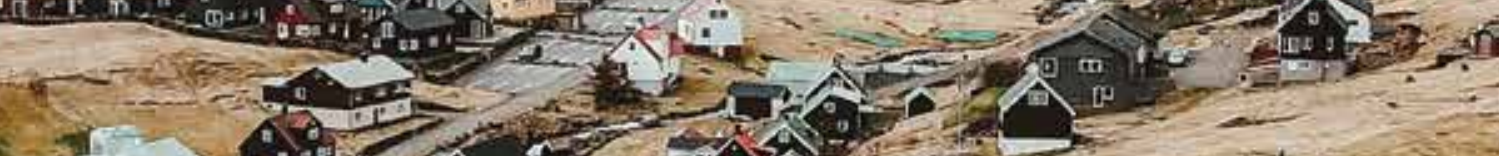

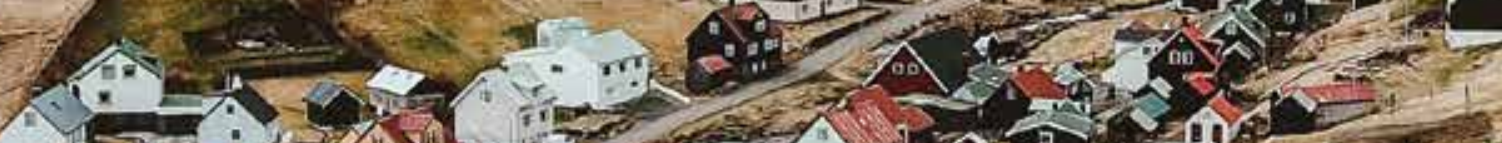

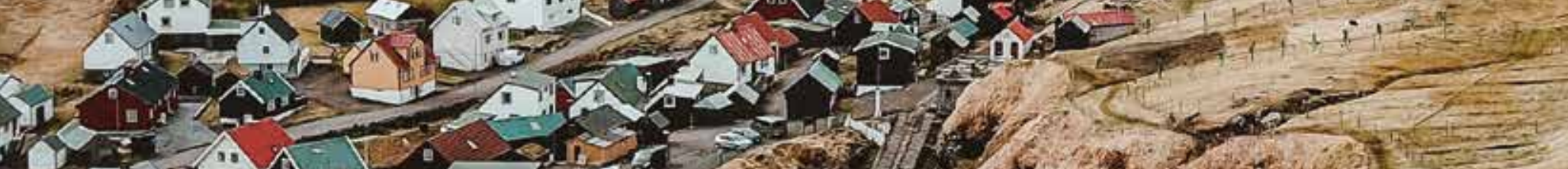

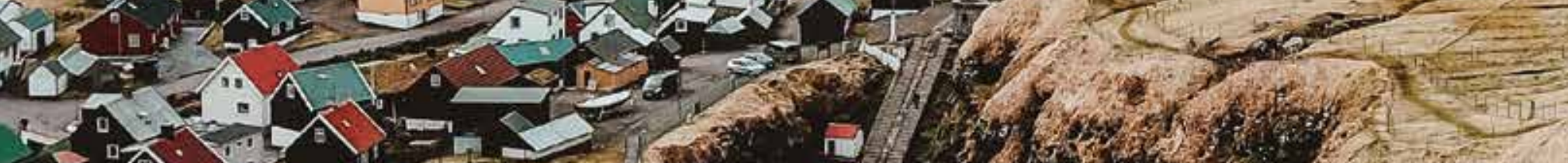
10
"4. nit 2 


\section{Information work}

The information service of the Nordic Council of Ministers, Hello Norden, and the three regional information services, Nordkalottens Gränstjänst, Grensetjänsten and Øresunddirekt, are particularly important for the Nordic work on freedom of movement, and are financed to varied extents by the Nordic Council of Ministers.

The information services are useful for private persons and businesses who wish to move between the Nordic countries and who need help to find information about regulations and contacts with public agencies.

These services form the strategic frontline of the Freedom of Movement Council. They register all obstacles, and analyse how they can be resolved locally, regionally or nationally. The identified obstacles are then reported to the Secretariat of the Freedom of Movement Council, and entered in the Nordic Freedom of Movement Database.

In 2017, the information services together generated over 1,950,000 web visits, and over 36,000 personal contacts (visits, email, telephone and group visits).

The work to remove obstacles has been streamlined by the Secretariat of the Freedom of Movement Council working with the information services to develop a common collaboration platform, the 'LOTS group' (Nordic Solution-Oriented Duty Co-ordinator). This group meets four times a year.

The group has produced a joint action plan for how to streamline the freedom of movement work and the information initiatives.

In addition to the information services, the LOTS group includes 11 of 12 regional committees. These work with freedom of movement issues, and also play an important role in the work to remove obstacles.

The operative collaborations implemented within the framework of the action plan in 2016 included a conference on cross-border obstacles in the labour market area with a focus on unemployment benefit in Sweden, 12-13 October 2016, and two Interreg projects aimed at increasing mobility for small and medium-sized companies in the Nordic region. The project 'Development of Nordkalottens gränstjänst's business advice service' is being implemented in the border region of Nordkalotten, which involves Sweden, Norway and Finland. The project 'Border Opportunities' is being run along the entire Norway-Sweden border.

The Secretariat of the Freedom of Movement Council also participates in the policy groups of the regional information services, which sometimes participate in the Hello Norden working group.

When the members of the Freedom of Movement Council hold meetings in advance of the Council's ordinary meetings, the information services and the regional committees participate in these.

In the coming years, the ambition is to increase coordination between Hello Norden and the regional committees to improve efficiency and increase the added value of the information activities. 


\begin{tabular}{|c|c|c|c|c|c|}
\hline & $\begin{array}{l}\text { Visits to } \\
\text { website }\end{array}$ & $\begin{array}{l}\text { Faceook } \\
\text { followers }\end{array}$ & $\begin{array}{r}\text { Twitter } \\
\text { followers }\end{array}$ & $\begin{array}{r}\text { Personal } \\
\text { service }\end{array}$ & $\begin{array}{r}\text { Information meetings } \\
\text { and seminars }\end{array}$ \\
\hline Hello Norden & $1,000,298$ & 8,907 & 1,023 & 2,560 & 2,000 \\
\hline $\begin{array}{l}\text { Nordkalottens } \\
\text { gränstjänst SWE/FIN/NOR }\end{array}$ & 25,830 & 540 & & 3,391 & 1,209 \\
\hline Grensetjänsten SWE/NOR & 141,796 & 558 & 92 & 15,474 & 1,405 \\
\hline Øresunddirekt SWE/DNK & 788,113 & 1,576 & 642 & 14,844 & 6,306 \\
\hline Total & $1,956,037$ & 11,581 & 1,757 & 36,269 & 10,920 \\
\hline
\end{tabular}




\section{Member of the Freedom of Movement Council}

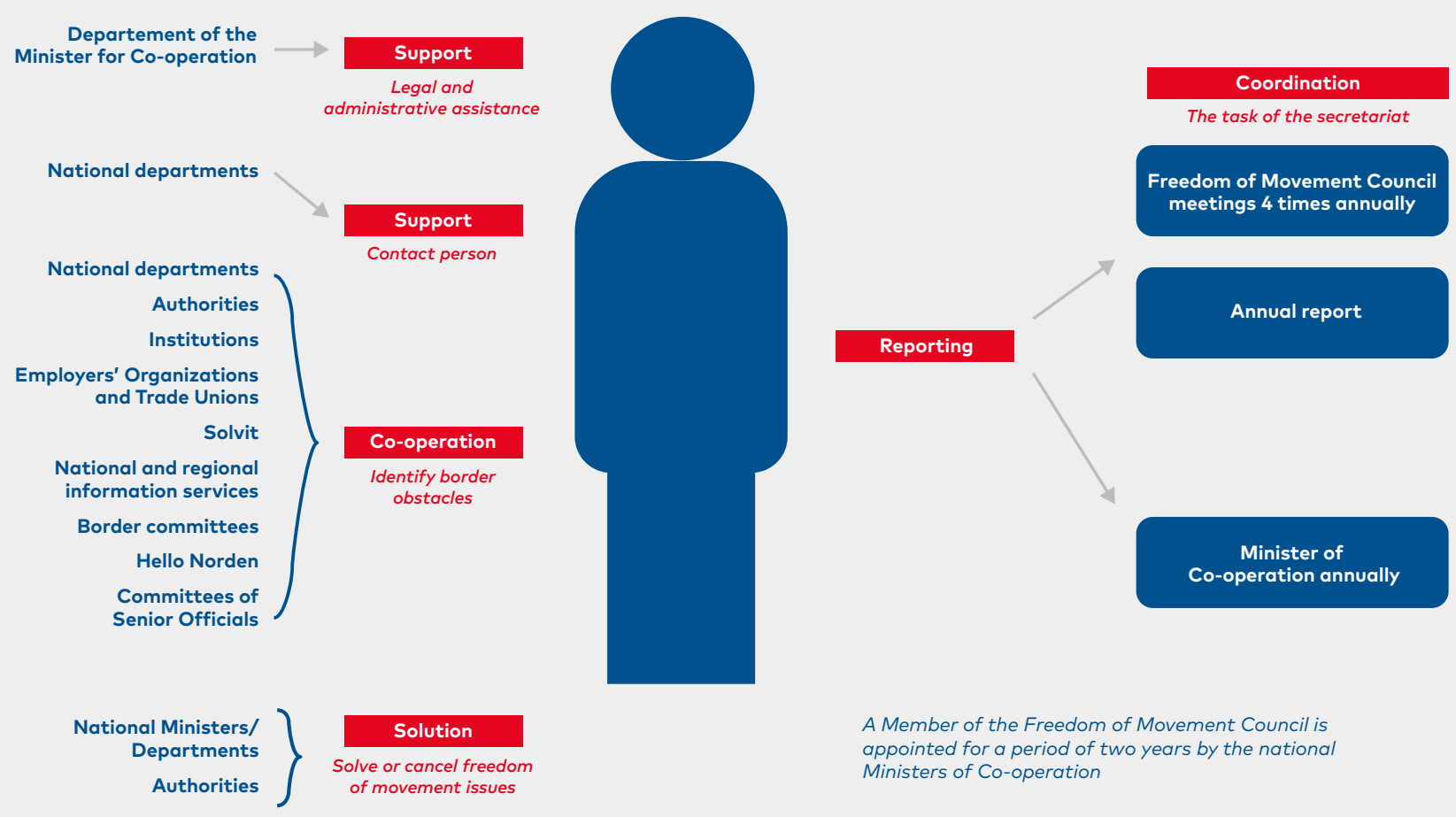




\section{Mandate of the Freedom of Movement Council, 2018-2021}

\section{Background}

The work to remove cross-border obstacles is a high priority in the Nordic collaboration. It comprises an important, although limited, component in the work to attain the Prime Ministers' vision that the Nordic region is to be the most integrated region in the world. The overall aim of the work is therefore to promote mobility and trade between the Nordic countries for citizens and businesses.

The Nordic co-operation is an interstate collaboration, so it is the national parliaments, ministries, public agencies and other actors that are responsible for working to remove intentional/undesirable border obstacles.

The Freedom of Movement Council will work to remove obstacles to freedom of movement that affect citizens and businesses in the Nordic region. The role of the Council's national members is to exert influence on the national and political administrative systems. Council members should be able to approach ministers in the Nordic countries directly if this is deemed necessary to conclude the process on an obstacle.

The Council will identify, prioritise and help remove border obstacles for citizens and businesses in the Nordic region, in collaboration with all the relevant bodies, including national administrations and agencies, parliamentarians, information services, and labour market parties.

The work in the Council will be closely linked with the presidency of the Council of Ministers, its priorities and political leadership, and the Secretary General will be a driving force in the work on freedom of movement in the Council of Ministers.

\section{Members of the Freedom of Movement Council} Sweden, Denmark, Norway, Iceland, Finland, the Faroe Islands, Greenland and Åland can each appoint members to the Freedom of Movement Council.

When appointing members, in addition to national priorities, emphasis should be placed on the members satisfying the following criteria. Members should have:

- a strong and current network in the national governments, at ministerial and/or senior official level

- experience of work in one or more of the areas in which most border obstacles are found (labour market, social policy, tax, education or business)

- the necessary capacity to prioritise the work in the Freedom of Movement Council

- the necessary freedom to take action in the work to remove border obstacles; this means they must be able to make decisions based on their own assessments, and hold national meetings with relevant ministers and department employees, when necessary. This enables members to identify and prioritise the border obstacles that they feel are important.

In addition to the national members, the Secretary General of the Nordic Council of Ministers is a member of the Freedom of Movement Council, which also includes a member from the Nordic Council.

In the composition of the Council, an even gender distribution is desirable.

\section{Presidency of the Freedom of Movement Council}

The presidency of the Freedom of Movement Council rotates, following the presidency of the Nordic Council of Ministers. The presidency leads the work of the Council in collaboration with the Secretary General of the Nordic Council of Ministers.

The presidency of the Freedom of Movement Council will have continual and close dialogue with its national representative in the Nordic Committee for Cooperation (NSK) and the ministers for co-operation, in order to ensure agreement between the priorities of the presidency country in general and the work in the Freedom of Movement Council. This dialogue must also take place before the start of the year of the presidency, to ensure that border obstacles are included in the presidency programme for the Nordic 
Council of Ministers. All national members should have continual and close dialogue with their national NSK representative and minister for co-operation, to ensure progress with each country's prioritised border obstacles.

The presidency of the Freedom of Movement Council will make an annual report about the work of the Council available to the prime ministers, if the presidency of the Council of Ministers at the time deems that there is a need to raise the issues at prime minister level.

Finally, the presidency of the Freedom of Movement Council will also ensure that priorities in previous years are carried forward in the work.

\section{Remit}

The quantitative goal for the Freedom of Movement Council is to conclude the processing of 8-12 obstacles per year. 'Concluded' means that the obstacle has been resolved, or discontinued, i.e. that the obstacle cannot be resolved. This decision is reported, and the Freedom of Movement Council then stops working with the obstacle in question.

Quantitative goals will be complemented with qualitative goals. These will be set after discussions in the Freedom of Movement Council, and with consideration of the citizen and business perspective and national and regional conditions, and will ensure that the prioritised obstacles are significant to mobility in the Nordic region.

The results of the work will be continually monitored closely, along with any need for changes that can help to resolve even more and significant obstacles, to help citizens and businesses in the Nordic region. The concluded obstacles will also be continually monitored.

In collaboration with relevant actors in the Nordic countries, the Freedom of Movement Council will:

- Identify and investigate border obstacles facing citizens and businesses in the Nordic region in response to input from, for example, Hello Norden and the regional information services.

- In collaboration with the countries, try to find solutions to the obstacles to freedom of movement.

- Decide which obstacles are most important for the Council to work with in relation to citizens, businesses and the countries. Assess the importance of the obstacle and then decide on the most suitable level for further contacts (MR/EK, national ministries, or at a more operative level, such as public agencies, working groups, institutions, and sector organisations).

- Help to prevent countries creating new crossborder obstacles in connection with new national legislation and implementation of EU/EEA regulations. This will involve close dialogue with the relevant ministries.

- Establish collaboration with SOLVIT nationally and, as far as possible, report to SOLVIT obstacles that are illegal in terms of EU law. Cases that are referred to SOLVIT may be processed in the Council.

- Collaboration with regional information services, border committees and Hello Norden, to identify and report obstacles to NMRS and the Freedom of Movement Database. These are then checked by the NMRS/Freedom of Movement Council in collaboration with the ministries concerned. Issues that are identified as causing tangible problems for citizens and businesses, but that do not qualify as obstacles, are forwarded for processing in other relevant fora.

- Collaboration with councils of ministers and committees of senior officials under the Nordic Council of Ministers, national administrations and public agencies.

The Freedom of Movement Council can also:

- represent the work on freedom of movement: hold meetings with ministers and senior officials (MREK) on cross-border obstacles, hold presentations at conferences, etc.

- initiate relevant analyses and arrange solutionoriented seminars, etc, that can support the work of removing cross-border obstacles in the Nordic region.

The Council meets approximately four times a year as necessary, with an annual kick-off meeting held in connection with the start of a new presidency. The focus is on evaluating and further developing the work.

There is the greatest possible information exchange with, and transparency in relation to, the Nordic Council freedom of movement group. 


\section{Tasks of the national members of the Free- dom of Movement Council}

Each member of the Freedom of Movement Council is responsible for ensuring national support for the work of removing obstacles. Members should therefore establish collaboration with the national bodies that are important in resolving cross-border obstacles, such as national agencies, labour market partners, information services, etc.

Each national member will have a suitable tool for this task. This will involve setting up a national network group, which holds regular meetings in connection with the work in the Freedom of Movement Council. In the groups, the agenda for meetings in the Freedom of Movement Council will be discussed and reviewed. Current obstacles can be raised, status of ongoing processes reviewed, and current activities discussed.

The network group can consist of the following regional and national participants:

- The national member of the Freedom of Movement Council

- Officials from the national NSK office

- Permanent representation from the most relevant ministries and public agencies, and other agencies relevant to the agenda of the meeting

- The regional information services

- Hello Norden

- Relevant parliamentarians from the national delegation to the Nordic Council

- Labour market partners when this is relevant to the meeting's agenda

- Possibly a participant from NMRS

- Possibly a participant from the national ombudsman institution

Through these groups, Nordic networks will be set up and developed in particular focus areas according to need.

In addition to the national networks, where most of the national work on freedom of movement takes place, the ministers for co-operation and the member of the Freedom of Movement Council may be called to meetings with the ministers concerned, where the Freedom of Movement Council's prioritised obstacles are discussed.

Every year, the individual members of the Freedom of Movement Council report to the national ministers for co-operation on the activities that have been initiated nationally in the work to eliminate cross-border obstacles.

The Freedom of Movement Council member reports, to the ministers for co-operation, work done nationally to eliminate obstacles, based on the Annual Report of the Freedom of Movement Council. The report also presents the measures that are planned in the subsequent years regarding remaining and new prioritised cross-border obstacles.

\section{Role of the Secretary General}

As a member of the Freedom of Movement Council, the Secretary General has some particular tasks:

- Transfer cases arising from the work in the Freedom of Movement Council to the relevant Council of Ministers and Committee of Senior Officials under the Nordic Council of Ministers.

- Help to ensure good coordination and organisation of the work.

- Ensure that the work in the Freedom of Movement Council is reported to the Session of the Nordic Council, to form part of the annual presentation of the ministers for co-operation regarding the work to remove obstacles.

The Secretary General places the Secretariat of the Nordic Council of Ministers at the disposal of the Freedom of Movement Council to assist in its work. The Secretariat coordinates the work, prepares materials for meetings, and conducts practical work in connection with planning and holding meetings. The Secretariat is responsible for the Freedom of Movement Database.

The Secretary General is responsible for preparing the agenda and position on decisions, but the work is carried out in dialogue with the relevant presidency of the Freedom of Movement Council.

\section{Role of the countries}

To support the work of the Freedom of Movement Council, the countries assist as much as possible with legal and professional expertise, as and when necessary. Each country appoints a contact person in all relevant ministries. This person, who is the point of entry to the ministry, can help the Freedom of Movement Council with the necessary contacts that can be useful in the work to identify, investigate and find solutions to obstacles. 
The countries are responsible for providing any services to their national members, both professional and practical. The members of the Freedom of Movement Council are also responsible for bookings and other logistical activities relating to the task.

\section{Budget, fees, etc}

Funding is allocated in the Nordic budget to the work of the Freedom of Movement Council, including funds for commissioning analyses and investigations by external actors.

Depending on the regulations in their home countries, the country representatives in the Freedom of Movement Council may receive an annual remuneration/ fee from the Nordic budget for the work in the Council, but expenses relating to travel, meetings, etc. are paid nationally by each country.

The period of the mandate is 1 January 2018 - 31 December 2021. In connection with reporting after 2019, the ministers for co-operation (MR-SAM) provide a status report on the experiences relating to the mandate. 


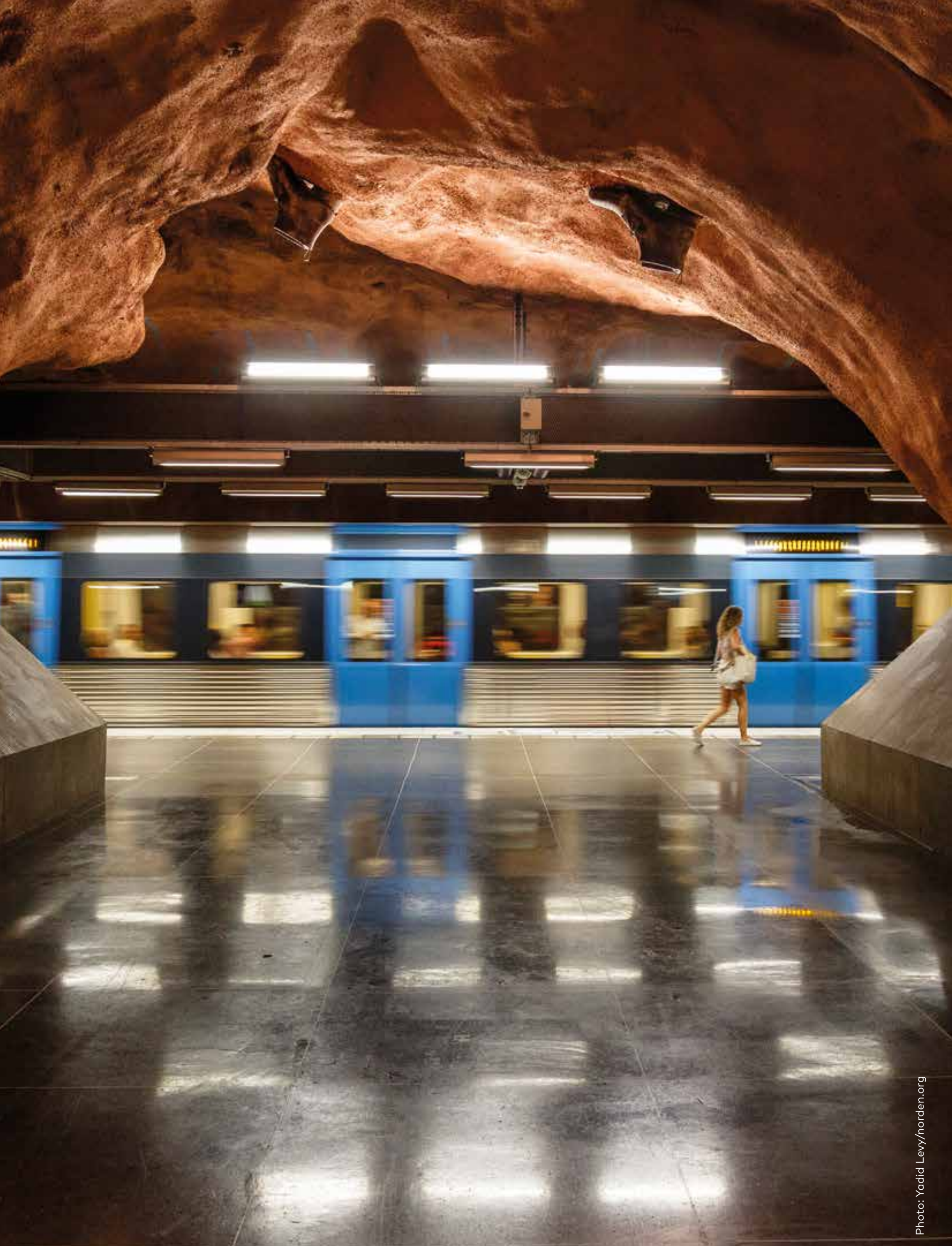


11

Nordic Council of Ministers

Nordens Hus

Ved Stranden 18

DK-1061 Copenhagen

www.norden.org

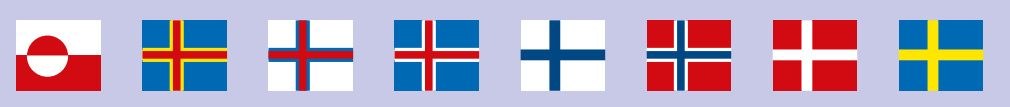

$25-19-13-9-5-3-1$

$33-26-20-14-10-6$
$39-34-27-21-15-7$
4

$45-40-35-28-4-16-11-8$

$49-46-41-29-22-17-12$

$53-50-42-36-30-23-18$

$55-41-47-43-31-24$

$56-54-52-48-44-38-32$ 